\title{
ARAŞTIRMA / RESEARCH \\ Chromosomal aberrations in multiple myeloma: clinical outcome and response to bortezomib
}

Multiple myelom'da kromozomal aberasyonlar: klinik sonuçlar ve bortezomib’ e yanıt

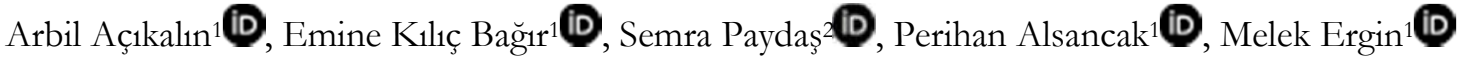 \\ ${ }^{1}$ Cukurova University Medical Faculty, Department of Pathology, ${ }^{2}$ Department of Medical Oncology, Adana, Turkey
}

\section{Cukurova Medical Journal 2019;44(2):395-401}

\begin{abstract}
Purpose: Multiple myeloma is a heterogeneous disease, for which an understanding of the prognostic and predictive value of chromosomal aberrations is necessary to prescribe the most appropriate therapy. We aimed to document the frequencies of chromosomal aberrations in our institute and searched the relationships between therapy regimens and chromosomal aberrations.

Materials and Methods: We analyzed the frequency of del(17p13), del(13q14), t(11;14), and $t(4 ; 14)$ in patients with MM by interphase-fluorescent in situ hybridization who were diagnosed between January 2010 and December 2015 in our institute. We researched the relationship between response to conventional chemotherapy and Bortezomib based chemotherapy.
\end{abstract}

Results: Eighty patients $(72.7 \%)$ had at least one chromosomal aberration. The most frequently observed aberration was $\operatorname{del}(17 p 13)(48.2 \%)$, followed by $\operatorname{del}(13 q 14)$ $(40.9 \%), t(11 ; 14)(16.4 \%)$, and $t(4 ; 14)(11.8 \%)$. In clinically analyzed subgroup $(\mathrm{n}=67), 36$ patients who received Bortezomib based chemotherapy showed a higher response rate $(55.6 \%)$ than conventional chemotherapy group $(48.4 \%)$. With respect to chromosomal aberrations, response rates were higher in Bortezomib based therapy group $(63.2 \%)$ than conventional chemotherapy group $(50 \%)$ in del (17p13) positive patients as well as in del (13q14) positive patients (61.5\% in Bortezomib based, $50 \%$ in conventional chemotherapy group).

Conclusion: Bortezomib-containing regimens may have beneficial effects on the clinical outcome of patients with $\operatorname{del}(17 p 13)$ and $\operatorname{del}(13 q 14)$.

Keywords: Bortezomib, chromosomal aberration, multiple myeloma
Öz

Amaç: Mutltiple myelom heterojen bir hastalık olup, en etkin tedavinin planlanlanabilmesi için kromozomal aberasyonların prognostik ve prediktif değerlerinin anlaşılması önemlidir. Bu çalışmada kurumumuzda tanı almış hastaların kromozomal aberasyonlarının sıklığını ve tedavi seçenekleri ile arasındaki ilişkiyi araştırmayı amaçladık.

Gereç ve Yöntem: Ocak 2010 ve Aralık 2015 tarihleri arasında kurumumuzda tanı almış multiple myelomlu hastalarda, interfaz-floresan in situ hibridizasyon yöntemi ile $\operatorname{del}(17 p 13), \operatorname{del}(13 q 14), t(11 ; 14)$, and $t(4 ; 14)$ kromozomal aberasyonlarının sıklığını araştırdık. Bu sonuçların, konvansiyonel kemoterapi alan hastalar ile bortezomib tabanlı kemoterapi alan hastalardaki yanıtlarını karşılaştırdık.

Bulgular: Seksen hastada $(\% 72.7)$ en az bir adet kromozomal aberasyon saptandi. En s1k saptanan aberasyon del(17p13) (\%48.2) idi. Bunu sirasiyla del(13q14) $(\% 40.9), \quad t(11 ; 14) \quad(\% 16.4)$, ve $t(4 ; 14) \quad(\% 11.8)$ takip etmekteydi. Klinik bulgularına ulaşılabilen 67 hastalık grupta, Bortezomib tabanlı kemoterapi alan 36 hastanın tedaviye yanıt oranı $(\% 55.6)$ konvansiyonel kemoterapi alan gruba oranla (\%48.4) daha yüksek idi. Kromozomal aberasyonlar ile karşılaştırıldığında; del (17p13) saptanan hastaların Bortezomib tabanlı kemoterapiye yanitları (\%63.2), konvansiyonel kemoterapi alanlardan (\%50) daha yüksek saptandi. Benzer şonuç; del (13q14) saptanan hastalarda da gözlendi (Bortezomib alanlarda \%61.5, konvansiyonel kemoterapi alanlarda \%50).

Sonuç: Bortezomib içeren tedaviler özellikle del (17p13) ve del (13q14) aberasyonu saptanan hastalarda daha iyi sonuç vermektedir.

Anahtar kelimeler: Bortezomib, kromozomal aberasyon, multiple myelom

Yazışma Adresi/Address for Correspondence: Dr. Arbil Açıkalın, Cukurova University Medical Faculty, Department of Pathology, Adana,Turkey. E-mail: arbilacikalin@gmail.com

Geliș tarihi/Received: 07.10.2018 Kabul tarihi/Accepted: 08.12.2018 Çevrimiçi yayın/Published online: 24.02.2019 


\section{INTRODUCTION}

Multiple myeloma (MM) is a malignant plasma cell neoplasm that is characterized by multistep oncogenesis. MM comprises $10-15 \%$ of the hematopoetic neoplasms and is responsible for $20 \%$ of all deaths from hematologic malignancies ${ }^{1}$. Despite the development of novel therapies, MM remains an incurable disease. Over the last few decades, studies have focused on the prognostic and predictive value of chromosomal aberrations in MM. In this respect, interphase fluorescent in situ hybridization (FISH) has been widely accepted as superior to conventional cytogenetic methods because of the low proliferation rate of neoplastic plasma cells ${ }^{2}$. Chromosomal aberrations are detected in $30-45 \%$ of $\mathrm{MM}$ patients when conventional cytogenetic methods are used, whereas this ratio increases to approximately $80 \%$ with FISH ${ }^{3}$. In recent years, novel agents such as immunomodulators (thalidomide, lenalidomide) and proteasome inhibitors (bortezomib, carfilzomib) have been widely used and have shown higher and deeper response rates in patients with MM. We aimed to analyze the frequency of four structural $[\operatorname{del}(17 p 13)$, $\operatorname{del}(13 q 14), t(11 ; 14), \mathrm{t}(4 ; 14)$ ] chromosomal aberrations in 110 Turkish MM patients and to correlate them with response to chemotherapy in 67 patients who were eligible for further evaluation.

\section{MATERIALS AND METHODS}

In this retrospective study, we included 110 newly diagnosed MM patients who were studied for chromosomal aberrations using interphase-FISH between January 2010 and December 2015, in our institute. This group was referred to as the entire group. Sixty-seven of these patients who were available for inclusion in the study and had not been lost to followup, returned to another hospital for further treatment, or given up treatment were referred to as the clinically analyzed subgroup. The clinically analyzed subgroup of patients was evaluated for the presence of plasmacytoma, response to therapy, relapse, and overall survival. The median follow-up period was 27.0 months (min: 1 month; max: 98 months).

Patients were selected as two different regimen groups. Conventional chemotherapy regimens included Vincristine, dexamethasone, and doxorubicin. Thirty-six patients received bortezomib-based chemotherapy, which consisted of bortezomib plus dexamethasone and zoledronic acid, thalidomide, or cyclophosphamide. Chemotherapy was the first-line therapy in these patients, who underwent 2-6 courses of treatment. Response to therapy was assessed according to the International Myeloma Working Group criteria, classified as "stable disease (SD), partial response (PR), very good partial response (VGPR), and complete response (CR)". For statistical analysis, efficacy was grouped into the response-positive (PR or better than $\mathrm{PR}$ ) and response-negative $(\mathrm{SD})$ categories. This retrospective study was not directly realized on human subjects but on the human tissue samples preserved in the archive of Department of Pathology and Oncology of Cukurova University, so Ethics Committee Approval was not indicated.

\section{Interphase-FISH}

Bone marrow aspiration samples were hybridized with florescent-labeled probes according to the manufacturers' instructions. TP53/CEP17 FISH probe kit (Vysis, Abbott Global, US) was used for $17 p 13$ deletions. LSI 13 (RB1) $13 q 14$ (Vysis, Abbott Global, US) was used for $13 q 14$ deletions. Probes of LSI IgH/CCDN1 (Vysis, Abbott Global, US) and LSI IgH/FGFR3 (Vysis, Abbott Global, US) were used to detect $t(11 ; 14)(q 13 ; q 32)$ and $t(4 ; 14)(p 16 ; q 32)$ translocations, respectively. Slides were analyzed using an Olympus BX61 florescent attachment microscope with the Bioview duet (ver.2.6, Israel) software. Two hundred nuclei with plasma cell morphology which were visualized by DAPI (4',6diamidino-2-phenylindole) were scored for each probe. The cut-off level for positive values for each probe was $10 \%$.

\section{Statistical analysis}

All statistical analyses were performed using the SPSS software for Mac (version 20.0). Correlations of the FISH results with gender, age, response to therapy, and relapse rate were analyzed using chi-square tests.

\section{RESULTS}

The median age was 60.0 (25-85) years. The male/female ratio was 1.07 (57/53). In this group, the overall rate of chromosomal aberration was $72.7 \%$ $(80 / 110)$, with the most frequent aberration being $17 p 13$ deletion in $48.2 \%(53 / 110)$ of the patients. The second most frequent aberration was $13 q 14$ deletion in $40.9 \%(45 / 110)$, followed by $t(11 ; 14)$ and $t(4 ; 14)$, 
which were detected in $16.4 \%(18 / 110)$ and $11.8 \%$ $(13 / 110)$ of the patients, respectively (Table 1$)$. Thirty patients $(27.3 \%)$ did not demonstrate any chromosomal aberration, while 41 patients $(37.3 \%)$ had one, 29 patients $(26.4 \%)$ had two, and 10 patients $(9.1 \%)$ had three chromosomal aberrations. The distribution of the chromosomal aberrations is detailed in Table 2.

Table 1. Demographic characteristics of patients and frequencies of chromosomal aberrations of entire group (110 patients).

\begin{tabular}{|l|c|}
\hline & Number of cases \\
\hline Mean age (years) & 60.5 (min:28, max: 85$)$ \\
\hline Gender: & \\
\hline Male: & $57(51.8 \%)$ \\
\hline Female: & $53(48.2 \%)$ \\
\hline $17 \mathrm{p} 13$ deletion & $53(48.2 \%)$ \\
\hline $13 \mathrm{q} 14$ deletion & $45(40.9 \%)$ \\
\hline $\mathrm{t}(11 ; 14)$ & $18(16.4 \%)$ \\
\hline $\mathrm{t}(4 ; 14)$ & $13(11.8 \%)$ \\
\hline
\end{tabular}

Table 2. Distribution of the chromosomal aberrationsin terms of combinations.

\begin{tabular}{|c|c|}
\hline $\begin{array}{l}\text { Only one chromosomal } \\
\text { aberration }\end{array}$ & $\begin{array}{l}\text { Number of } \\
\text { patients }\end{array}$ \\
\hline del17p13 & 24 \\
\hline del13q14 & 8 \\
\hline $\mathrm{t}(11 ; 14)$ & 6 \\
\hline $\mathrm{t}(4 ; 14)$ & 3 \\
\hline Total & 41 \\
\hline $\begin{array}{l}\text { Two chromosomal } \\
\text { aberrations }\end{array}$ & $\begin{array}{l}\text { Number of } \\
\text { patients }\end{array}$ \\
\hline del17p13 and $\mathrm{t}(11 ; 14)$ & 2 \\
\hline del17p13 and $d e \ell 13 \mathrm{q} 14$ & 19 \\
\hline del17p13and $\mathrm{t}(4 ; 14)$ & 1 \\
\hline del13q14 and $\mathrm{t}(11 ; 14)$ & 4 \\
\hline del13q14 and $\mathrm{t}(4 ; 14)$ & 3 \\
\hline $\mathrm{t}(11 ; 14)$ and $\mathrm{t}(4 ; 14)$ & None \\
\hline Total & 29 \\
\hline $\begin{array}{l}\text { Three chromosomal } \\
\text { aberrations }\end{array}$ & $\begin{array}{l}\text { Number of } \\
\text { patients }\end{array}$ \\
\hline $\begin{array}{l}\text { del17p13 and } \mathrm{t}(11 ; 14) \text { and } \\
\text { del13q14 }\end{array}$ & 4 \\
\hline $\begin{array}{l}\text { del17p13 and } d e / 13 \mathrm{q} 14 \text { and } \\
\mathrm{t}(4 ; 14)\end{array}$ & 4 \\
\hline$d e / 13 \mathrm{q} 14$ and $\mathrm{t}(4 ; 14)$ and $\mathrm{t}(11 ; 14)$ & 2 \\
\hline$d e \ell 17 \mathrm{p} 13$ and $\mathrm{t}(11 ; 14)$ and $\mathrm{t}(4 ; 14)$ & None \\
\hline Total & 10 \\
\hline
\end{tabular}

Sixty-seven of the 110 patients were eligible to have their FISH results correlated with clinical outcomes. In this subgroup, the median age was 59.0 (30-85) years, and the male/female ratio was $1.4(39 / 28)$. Twenty patients $(29.9 \%)$ were found to have plasmacytoma. Ig subtypes were available in 50 of the
67 patients and were distributed as follows: $32 / 50$ IgG, 10/50 IgA, 6/50 non-secretory, and 2/50 IgM. Response rates were $53.1 \%, 50 \%, 33.3 \%$, and $100 \%$ in terms of Ig subtypes, respectively. This result was not significant statistically.

The most frequent chromosomal aberration was $13 q 14$ deletion in $50.7 \%$ (34/67), followed by $17 p 13$ deletion in $49.3 \%(33 / 67)$. In this subgroup, $t(11 ; 14)$ was present in $20.9 \%(14 / 67)$ of the patients, and $t(4 ; 14)$ was the least frequent aberration, being detected in $13.4 \%(9 / 67)$ of the patients. Chromosomal aberrations were not found to be related to age or gender either in the entire group or in this subgroup.

Sixteen patients (23.9\%) demonstrated no chromosomal aberrations. Twenty-three of the 67 patients $(34.3 \%)$ had two chromosomal aberrations, 20 of the $67(29.9 \%)$ had one, and 8 of the $67(11.9 \%)$ had three chromosomal aberrations.

The most frequently paired chromosomal aberration was $\operatorname{del}(17 p 13)+\operatorname{del}(13 q 14)(14 / 23)$. This was followed by del(13q14) +t(11;14) $(3 / 23)$; del(13q14) + $t(4 ; 14)(3 / 23) ; \operatorname{del}(17 p 13)+t(11 ; 14)(2 / 23) ;$ and $\operatorname{del}(17 p 13)+t(4 ; 14)(1 / 23)$. Eight patients with three chromosomal aberrations were distributed as follows: four with $\operatorname{del}(17 p 13)+\operatorname{del}(13 q 14)+t(11 ; 14)$; two with $\operatorname{del}(17 p 13)+\operatorname{del}(13 q 14)+t(4 ; 14) ;$ and two with $\operatorname{del}(13 q 14)+t(11 ; 14)+t(4 ; 14)$. There was no relationship among these aberrations' co-existence.

Thirty-six of the 67 patients received bortezomibbased chemotherapy. Twenty of these 36 patients $(55.6 \%)$ showed a response to therapy (17 CR, 2 PR, 1 VGPR), while 15 of the 31 patients (48.4\%) who did not receive bortezomib showed a response (14 CR, 1 VGPR). Although the response rate was higher in the bortezomib group, this difference was not statistically significant $(\mathrm{p}=0.558)$. When the response was analyzed based on each chromosomal aberration, there was no statistically significant difference between the groups with and without bortezomib. We did, however, observed that the response rate was higher in del(17p13)- and del(13q14)-positive patients who were treated with a bortezomib-containing regimen compared to the conventional chemotherapy group. The comparative response rates in the bortezomib vs. no-bortezomib groups were $63.2 \%$ vs. $50 \%$ for $\operatorname{del}(17 p 13)$ positive patients and $61.5 \%$ vs. $50 \%$ for $\operatorname{del}(13 q 14)$ positive patients (Table 3).

The overall survival rate (OSR) was 55.2\% (37/67) 
over a median 27.0 month (min: 1 month; max: 98 months) follow-up period. The OSR in terms of the presence of chromosomal aberrations can be sorted from highest to lowest as follows: no chromosomal aberration $(62.5 \%)>t(11 ; 14)(57.1 \%)>\operatorname{del}(13 q 14)$ $(52.9 \%)>\operatorname{del}(17 p 13)(51.5 \%)>t(4 ; 14)(22.2 \%)$. These rates decreased significantly with increased chromosomal aberrations [1 chromosomal aberration $(60 \%)>2$ chromosomal aberrations $(52.2 \%)>3$ chromosomal aberrations $(37.5 \%)]$. The median time to patient death was 18.5 months (min: 1 month; max: 98 months), while the median survival was 35 months (min: 15 months; max: 79 months). Relapse occurred in 17 patients (25.4\%) at a median of 13.0 months (min: 4 months; max: 30 months).

OSR of del (17p13)-positive patients was higher in Bortezomib-based chemotherapy group (57.9\%) than conventional chemotherapy group (51.5\%). Whereas, OSRs were lower in del (13q14), t $(4 ; 14)$ and $t(11 ; 14)$ positive patients who received Bortezomibbased chemotherapy (Table 3).

The relapse rates were lower in del(17p13)-positive patients receiving bortezomib-based regimens $[27.3 \%(3 / 11)]$ than conventional chemotherapy group $[62.5 \%(5 / 8)]$. Similarly, del(13q14)-positive patients receiving bortezomib showed lower relapse rates $[40 \%(6 / 15)]$ than conventional chemotherapy group $[60 \%(3 / 5)]$ as well as patients with $t(4 ; 14)$. There was no difference in $t(11 ; 14)$ positive patients $(n=14)$ between the two therapy groups in terms of relapse $[50 \%(4 / 8)$ and 50\% (3/6)] (Table 3).

None of these results were found to be statistically significant, due to the small number of cases included in the present study.

Table 3. Clinical outcomes in bortezomib group in patients with chromosomal aberrations

\begin{tabular}{|l|c|c|c|c|c|c|}
\hline & \multicolumn{2}{|c|}{ Response } & \multicolumn{2}{c|}{ Relapse } & \multicolumn{2}{c|}{ Overall survival rate } \\
\hline & bortezomib & $\begin{array}{c}\text { No } \\
\text { bortezomib }\end{array}$ & bortezomib & $\begin{array}{c}\text { No } \\
\text { bortezomib }\end{array}$ & bortezomib & $\begin{array}{c}\text { No } \\
\text { bortezomib }\end{array}$ \\
\hline $\operatorname{del}(17 \mathrm{p})$ & $63.2 \%$ & $50 \%$ & $27.3 \%$ & $62.5 \%$ & $57.9 \%$ & $51.5 \%$ \\
\hline $\operatorname{del}(13 \mathrm{q})$ & $61.5 \%$ & $50 \%$ & $40 \%$ & $60 \%$ & $50 \%$ & $52.9 \%$ \\
\hline $\mathrm{t}(4 ; 14)$ & $40 \%$ & $50 \%$ & $50 \%$ & $100 \%$ & $20 \%$ & $25 \%$ \\
\hline $\mathrm{t}(11 ; 14)$ & $37.5 \%$ & $50 \%$ & $80 \%$ & $33.3 \%$ & $50 \%$ & $66.7 \%$ \\
\hline
\end{tabular}

\section{DISCUSSION}

MM is characterized by multiple complex chromosomal aberrations during oncogenesis, with almost all cases demonstrating cytogenetic changes. The earliest and most frequent genetic changes are translocations involving the $I g H$ gene locus on $14 q 32^{4}$. These changes begin in Monoclonal Gammopathy of Undetermined Significance (MGUS), and their incidence increases in MM and even more so in plasma cell leukemia ${ }^{4}$. Frequently detected translocations are $t(11 ; 14) \quad(q 13 ; q 32)$ (cyclinD1), $t(4 ; 14)(p 16 ; q 32)$ (FGFR3), and rarely; $t$ $(14 ; 16) \quad(q 32 ; q 23)$ (c-MAF) and $t(6 ; 14)(p 21 ; q 32)$ (cyclinD3) ${ }^{5}$. Most studies have suggested that the presence of $t(11 ; 14)$ alone is a favorable prognostic indicator. Additionally, patients who overexpressed cyclin D1 had significantly longer event-free survival (EFS) rates compared to patients who did not overexpress cyclin D1 ${ }^{6}$. Gertz, however, reported no difference between cyclin D1-positive and cyclin D1negative patients with respect to clinical presentation, laboratory characteristics (including chromosome 13 abnormalities), response to therapy, and overall survival ${ }^{7}$. This translocation is usually accompanied by other poor prognostic chromosomal aberration(s), so its incidence alone is low $(15 \%)^{8}$. In our study, $t$ $(11 ; 14)$ was present in $16.4 \%(18 / 110)$ of $\mathrm{MM}$ patients. Only $6 / 18(5.5 \%)$ patients had $t(11 ; 14)$ alone. The other 12 patients had at least one additional poor prognostic chromosomal aberration. Three of the six patients were available for follow-up, and although this number was small, all patients were alive at 35,46 , and 75 months, suggesting a favorable effect of this translocation.

$t(4 ; 14)$ leads to the up-regulation of the FGFR3 oncogene, which results in IL-6 independence and decreased apoptosis ${ }^{9} . t(4 ; 14)$ has been thought to be a negative prognostic indicator in previous studies, with the frequency of $t(4 ; 14)$ being $10-15 \% 0^{8,10,11}$. In the present study, $11.8 \%(13 / 110)$ of the MM patients had $t(4 ; 14)$, which is consistent with the literature. Three patients had only $t(4 ; 14)$, and seven patients had an accompanying $\operatorname{del}(13 q 14)$, which is also similar to previous series. This strong relationship is thought to be responsible for the negative effect of del(13q14) on survival ${ }^{12}$. Seven of the nine $t(4 ; 14)$-positive patients who were available 
for follow up died within a median 35.0 months (min: 4 months; max: 59 months).

Deletion of $17 p 13$ involving the p53 gene is reported in $5-30 \%$ of cases $2,3,13-15$. The $17 p 13$ deletion cannot be detected in MGUS; lower rates are observed in newly diagnosed or early-stage disease, while higher rates are observed in advanced-stage disease. This deletion is believed to be responsible for aggressive progressive disease and extramedullary involvement. This aberration is associated with advanced stage disease and lower response rates to therapy, irrespective of the treatment modality, including high-dose chemotherapy $8,14,16,17$. In the present study, a $17 p 13$ deletion was detected in $48.2 \%(53 / 110)$ of the entire group and in $49.3 \%$ (33/67) of the clinically analyzed subgroup. Our patients' results were higher than reported in the literature, which also have a wide range $(5-30 \%)$. We think that this difference is related to heterogeneity of the study groups and/or variability of the cut-off values. Twenty-three of the $33(69.7 \%)$ del (17p13)-positive patients also had one or more additional chromosomal aberration(s), with del (13q14) being the most frequent $(20 / 23)$. Six of the 10 patients with del (17p13) alone did not respond to therapy, regardless of the chemotherapy regimen, and five of the unresponsive patients died within a median of 14.0 months (min: 5 months; max: 23 months). These results support the poor prognostic value of a $17 p 13$ deletion.

A $13 q 14$ deletion is reported to be the most frequent chromosomal aberration, occurring in between 20 $63 \%$ of patients. The $40.9 \%$ rate observed in our study is consistent with previous reports ${ }^{18,19}$. Recent studies have concluded that RB1 region probes are more informative and sensitive in detecting $13 q 14$ deletions 2, 20, 21. In our study, the del(13q14) deletion was accompanied by other chromosomal aberrations in $82.3 \%(28 / 34)$ of the patients. Two of the six patients with the only del(13q14) mutation died within two and 13 months. Three of the six patients showed response to chemotherapy. Two of the four surviving patients relapsed in seven or 30 months. Del(13q14) is thought to be an independent adverse prognostic factor in patients treated with high-dose chemotherapy and stem cell support; patients with this deletion tend to have shorter survival ${ }^{18,19}$. Bortezomib is important in these cases because the patients' unfavorable prognosis has been improved with the use of this drug. Our patients receiving Bortezomib-based therapy showed better response and relapse rates.
Twenty patients with plasmacytoma showed mostly del (13q14) (12/20), and the most frequent paired aberration was $(17 p 13)+(13 q 14)$ deletions $(5 / 20)$. Five patients did not demonstrate any chromosomal aberration. To date, the correlations between chromosomal aberrations and the presence of plasmacytoma have not been widely examined. However, our results indicated that patients with plasmacytoma tended to have poor prognostic aberrations.

These investigations are designed to improve MM patients' prognosis by advancing novel agents such as thalidomide, lenalidomide, and bortezomib. Recent studies with bortezomib have shown improved survival and better response rates both in newly diagnosed and relapsed/refractory cases of MM, regardless of any chromosomal aberrations 16, 22-28. Some authors, however, do not agree with this suggestion ${ }^{29}$, 30. Aveit-Loiseau reported improved effects on event-free survival and OS in patients with $t(4 ; 14)$ who received bortezomib ${ }^{16}$. In our study, patients with $t(4 ; 14)$ who received bortezomib tended to relapse less compared to the no-bortezomib group, although the response and OS rates were not different.

He J searched $17 p 13$ and $13 q 14$ deletions, $14 q 32$ rearrengement and $1 q 21$ amplification by conventional cytogenetic analyses and by FISH. In their study, $49.2 \%$ of patients had at least one chromosomal aberration and they found that the differences in the response rates, progression-free survival, and OS between FISH negative and positive patients were less obvious in a bortezomib-based chemotherapy group than in a conventional chemotherapy group. They suggested that bortezomib could overcome the effects of cytogenetic aberrations 14 . When we evaluated patients in terms of bortezomib-based chemotherapy, we similarly demonstrated the beneficial effects of bortezomib on the relapse, response and overall survival rates in patients with del(17p13) compared to the conventional chemotherapy group.

Patients with the del(13q14) deletion who received bortezomib also tended to have improved outcomes in terms of relapse and response, similar to $t(4 ; 14)$ positive patients. However, the OSR was lower in patients receiving bortezomib, supporting the independent prognostic value of the del(13q14) deletion. Bortezomib receipt did not result in differences in response and $O S$ in $t(4 ; 14)$ and 
t(11;14)-positive patients. These correlations were not statistically significant, likely due to the small number of patients and to the co-existence with other aberration(s).

In conclusion, cytogenetic aberrations are important for both prognosis and treatment strategy. Del(17p13), del (13q14) and $t(4 ; 14)$ are the most commonly detected poor prognostic aberrations; they are detected more frequently by FISH compared to conventional cytogenetic methods. $t(11 ; 14)$ alone seems to be a good prognostic indicator in cases with MM, but it very rarely exists without another aberration. Our results demonstrate the beneficial clinical effects of bortezomib in MM patients, especially in those with del (17p13) and del (13q14), as a first-step therapy regimen.

Overall, evaluating the importance and significance of each chromosomal aberration is difficult because MM cells show multiple and complex genetic abnormalities that usually accompany one another. Additional studies with larger patient samples will be needed to detect significant results.

Yazar Katkıları: Çalışma konsepti/Tasarımı: ME, AA, SP; Veri toplama: -; Veri analizi ve yorumlama: SP, EB, AA; Yazı taslağı: AA, SP Içeriğin eleştirel incelenmesi: SP, ME; Son onay ve sorumluluk: AA EKB, SP, PA, ME; Teknik ve malzeme desteği: -; Süpervizyon: AA, SP, ME, EKB, PA; Fon sağlama (mevcut ise): yok.

Bilgilendirilmiş Onam: Katılımcılardan yazılı onam alınmışıır. Hakem Değerlendirmesi: Dış bağımsız.

Ç1kar Çatışması: Yazarlar çıkar çatıșması beyan etmemișlerdir. Finansal Destek: Yazarlar finansal destek beyan etmemislerdir.

Author Contributions: Concept/Design : ME, SP, AA; Data acquisition: -; Data analysis and interpretation: SP, EB, AA; Drafting manuscript: AA,. SP; Critical revision of manuscript: SP, ME; Final approval and accountability: AA, EKB, SP, PA, ME; Technical or material support: -; Supervision: AA, SP, ME, EKB, PA; Securing funding (if available): $\mathrm{n} / \mathrm{a}$.

Informed Consent: Written consent was obtained from the participants.

Peer-review: Externally peer-reviewed.

Conflict of Interest: Authors declared no conflict of interest.

Financial Disclosure: Authors declared no financial support

\section{REFERENCES}

1. McKenna RW, Kyle RA, Kuehl WM, Harris NL, Coupland RW, Fend F. Plasma cell neoplasms. In texbook of WHO Classification of Tumours of Haematopoietic and Lymphoid Tissues (Eds Swerdlow SH, Campo E, Harris NL, Jaffe ES, Pileri SA, Stein $\mathrm{H}$ et al) . France: IARC press. 2017.

2. Gmidene A, Avet-Loiseau H, Sennana H, Ben Abdallah I, Khlif A, Meddeb B et al. Molecular cytogenetic aberrations in Tunisian patients with multiple myeloma identified by cIg-FISH in fixed bone marrow cells. Cytogenet Genome Res. 2012;136:44-9.
3. Gao X, Li C, Zhang R, Yang R, Qu X, Qiu H, et al.Fluorescence in situ hybridization analysis of chromosome aberrations in 60 Chinese patients with multiple myeloma. Med Oncol. 2012; 29:2200-6.

4. Seidl S, Kaufmann H, Drach J.New insights into the pathophysiology of multiple myeloma. Lancet Oncology. 2003;4:557-64.

5. Avet-Loiseau H, Malard F, Campion L, Magrangeas F, Sebban C, Lioure B, et al. Translocation $t(14 ; 16)$ and multiple myeloma: is it really an independent prognostic factor? Blood. 2011;117:2009-11.

6. Soverini S, Cavo M, Cellini C, Terragna C, Zamagni $\mathrm{E}$, Ruggeri $\mathrm{D}$ et al. Cyclin D1 overexpression is a favorable prognostic variable for newly diagnosed multiple myeloma patients treated with high-dose chemotherapy and single or double autologous transplantation. Blood. 2003;102:1588-94.

7. Gertz MA, Lacy MQ, Dispenzieri A, Greipp PR, Litzow MR, Henderson KJ et al. Clinical implications of $\mathrm{t}(11 ; 14)(\mathrm{q} 13 ; \mathrm{q} 32), \mathrm{t}(4 ; 14)(\mathrm{p} 16.3 ; \mathrm{q} 32)$, and $-17 \mathrm{p} 13$ in myeloma patients treated with high-dose therapy. Blood. 2005;106:2837-40.

8. Segges P, Braggio E. Genetic markers used for risk stratification in multiple myeloma. Genet Res Int. 2011;798089.

9. Terpos E, Eleutherakis-Papaiakovou V, Dimopoulos MA. Clinical implications of chromosomal abnormalities in multiple myeloma. Leukemia \& Lymphoma. 2006;47:803-14.

10. Moreau P, Facon T, Leleu X, Morineau N, Huyghe P, Harousseau JL et al. Recurrent 14q32 translocations determine the prognosis of multiple myeloma, especially in patients receiving intensive chemotherapy. Blood. 2002;100:1579-83

11. Keats JJ, Reiman T, Maxwell CA, Taylor BJ, Larratt LM, Mant MJ et al. In multiple myeloma, $\mathrm{t}(4 ; 14)(\mathrm{p} 16 ; \mathrm{q} 32)$ is an adverse prognostic factor irrespective of FGFR3 expression. Blood. 2003;101:1520-9.

12. Fonseca R, Bergsagel PL, Drach J, Shaughnessy J, Gutierrez N, Stewart AK et al. International Myeloma Working Group molecular classification of multiple myeloma: spotlight review. Leukemia. 2009;23:221021.

13. Hu Y, Chen L, Sun CY, She XM, Ai LS, Qin. Clinical significance of chromosomal abnormalities detected by interphase fluorescence in situ hybridization in newly diagnosed multiple myeloma patients. Chin Med J (Engl). 2011;124:2981-5.

14. He J, Yang L, Meng X, Wei G, Wu W, Han X et al: A retrospective analysis of cytogenetic and clinical characteristics in patients with multiple myeloma. Am J Med Sci. 2013;345:88-93.

15. Durak BA, Akay OM, Sungar G, Bademci G, Aslan $\mathrm{V}$, Caferler $\mathrm{J}$ et al. Conventional and molecular cytogenetic analyses in Turkish patients with multiple myeloma. Turk J Haematol. 2012;29:135-42. 
16. Avet-Loiseau H, Leleu X, Roussel M, Moreau P, Guerin-Charbonnel C, Caillot D et al. Bortezomib plus dexamethasone induction improves outcome of patients with $t(4 ; 14)$ myeloma but not outcome of patients with del(17p). J Clin Oncol. 2010;28:4630-4.

17. Chang H, Yeung J, Qi C, Xu W. Aberrant nuclear p53 protein expression detected by immunohistochemistry is associated with hemizygous P53 deletion and poor survival for multiple myeloma. Br J Haematol. 2007;138:324-9.

18. Kroger N, Schilling G, Einsele H, Liebisch P, Shimoni A, Nagler A. et al. Deletion of chromosome band $13 \mathrm{q} 14$ as detected by fluorescence in situ hybridization is a prognostic factor in patients with multiple myeloma who are receiving allogeneic dose-reduced stem cell transplantation. Blood. 2004;103:4056-61.

19. Shaughnessy J, Jr., Tian E, Sawyer J, McCoy J, Tricot G, Jacobson J, et al: Prognostic impact of cytogenetic and interphase fluorescence in situ hybridizationdefined chromosome 13 deletion in multiple myeloma: early results of total therapy II. $\mathrm{Br} \mathrm{J}$ Haematol. 2003;120:44-52.

20. Yuregir OO, Sahin FI, Yilmaz Z, Kizilkilic E, Karakus $\mathrm{S}$, Ozdogu H. Fluorescent in situ hybridization studies in multiple myeloma. Hematology. 2009;14:90-4.

21. Zojer N, Konigsberg R, Ackermann J, Fritz E, Dallinger S, Kromer E et al: Deletion of 13q14 remains an independent adverse prognostic variable in multiple myeloma despite its frequent detection by interphase fluorescence in situ hybridization. Blood. 2000;95:1925-30.

22. San Miguel JF, Schlag R, Khuageva NK, Dimopoulos MA, Shpilberg O, Kropff M et al. Bortezomib plus melphalan and prednisone for initial treatment of multiple myeloma. N Engl J Med. 2008;359:906-17.
23. Romano A, Conticello C, Di Raimondo F. Bortezomib for the treatment of previously untreated multiple myeloma. Immunotherapy. 2013;5:327-52.

24. Sonneveld P, Goldschmidt H, Rosinol L, Blade J, Lahuerta JJ, Cavo M et al. Bortezomib-based versus nonbortezomib-based induction treatment before autologous stem-cell transplantation in patients with previously untreated multiple myeloma: a metaanalysis of phase III randomized, controlled trials. J Clin Oncol. 2013;31:3279-87.

25. Yang G, Chen W, Wu Y: Bortezomib, dexamethasone plus thalidomide for treatment of newly diagnosed multiple myeloma patients with or without renal impairment. Chin J Cancer Res. 2013;25:155-60.

26. Zeng Z, Lin J, Chen J: Bortezomib for patients with previously untreated multiple myeloma: a systematic review and meta-analysis of randomized controlled trials. Ann Hematol. 2013;92:935-43.

27. Zou Y, Lin M, Sheng Z, Niu S: Bortezomib and lenalidomide as front-line therapy for multiple myeloma. Leuk Lymphoma. 2014;55:2024-31.

28. Jiang A, Reece D, Chang H. Genomic stratification of multiple myeloma treated with novel agents. Leuk Lymphoma. 2012;53:202-7.

29. Richardson PG, Xie WL, Mitsiades C, Chanan-Khan AA, Lonial S, Hassoun $\mathrm{H}$ et al. Single-agent bortezomib in previously untreated multiple myeloma: efficacy, characterization of peripheral neuropathy, and molecular correlations with response and neuropathy. J Clin Oncol. 2009;27:3518-25.

30. Shaughnessy JD, Zhou YM, Haessler J, van Rhee F, Anaissie E, Nair B et al. TP53 deletion is not an adverse feature in multiple myeloma treated with total therapy 3. Br J Haematol. 2009;147:347-51. 